FROM SUNS TO LIFE: A CHRONOLOGICAL APPROACH TO THE HISTORY OF LIFE ON EARTH 


\title{
From Suns to Life: A Chronological Approach to the History of Life on Earth
}

\author{
Edited by \\ MURIEL GARGAUD \\ PHILIPPE CLAEYS \\ PURIFICACIÓN LÓPEZ-GARCÍA \\ HERVÉ MARTIN \\ THIERRY MONTMERLE \\ ROBERT PASCAL \\ JACQUES REISSE
}

Reprinted from Earth Moon, and Planets

Volume 98, Nos. 1-4, 2006

\section{黛 Springer}


A C.I.P catalogue record for this book is available from the library of Congress

ISBN 0-387-45082-7

ISBN 978-0-387-45082-7

Published by Springer,

P.O. Box 17, 3300 AA, Dordrecht, The Netherlands

www.springer.com

Printed on acid-free paper

Cover image: Persistence of Memory, 1931, (C) Salvadore Dali, Fundactión Gala-Salvador Dali, c/o Beeldrecht Amsterdam 2006

\section{All Rights Reserved}

(C) 2006 Springer

No part of this work may be reproduced, stored in a retrieval system, or transmitted in any form or by any means, electronic, mechanical, photocopying, microfilming, recording or otherwise, without written permission from the Publisher, with the exception of any material supplied specifically for the purpose of being entered and executed on a computer system, for exclusive use by the purchaser of the work.

Printed in the Netherlands 


\section{Table of Contents}

1 From the Arrow of Time to the Arrow of Life / M. GARGAUD and J. REISSE ......... 1-9

1.1 The Notion of Time in Astrobiology ............................................................... 1

1.2 Why, Where, When and How: Here are the Questions .......................................... 3

1.2.1 WHY? ........................................................................... 3

1.2.2 WHERE? ........................................................................ 4

1.2.3 WHEN (AND HOW)? ....................................................... 4

1.3 Our Modest Contributions to the "When" (and "How"?) Answers ....................... 5

1.3.1 THE "WHEN AND WHERE" MAKING-OF .................................... 5

1.3.2 THE "WHY" MAKING-OF ............................................................ 5

1.3.3 THE “HOW” MAKING-OF .......................................................... 6

2 Dating Methods and Corresponding Chronometers in Astrobiology / M. GARGAUD, F. ALBARÈDE, L. BOITEAU, M. CHAUSSIDON, E. DOUZERY and T. MONTMERLE

2.1 Astronomy: Dating Stellar Ages with the "Herzsprung-Russell Diagram” .......... $\quad 11$

2.2 Geochemistry: Principles of Radioactive Dating.............................................. $\quad \mathbf{1 6}$

2.2.1 LONG-LIVED CHRONOMETERS.................................................. 19

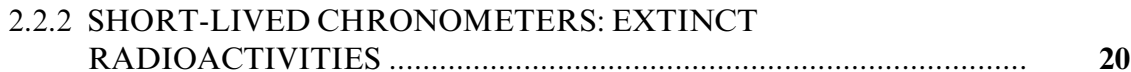

2.2.3 THE LIMITS OF THE METHOD ................................................... 22

2.3 Chemistry: The Impossible use of Chemical Clocks in a Prebiotic Scope................ $\quad 23$

2.3.1 SOME CHEMICAL CLOCKS AND THEIR LIMITS …................... $\quad \mathbf{2 5}$

2.3.2 CONCLUSIONS ........................................................................ 26

2.4 Biology: The Molecular Clocks ……....................................................................... 27

2.4.1 HISTORICAL PERSPECTIVE ON THE MOLECULAR CLOCK ..... $\quad 27$

2.4.2 THE GLOBAL MOLECULAR CLOCK: A SINGLE RATE APPROACH................................................................................ 29

2.4.3 THE LOCAL MOLECULAR CLOCKS: A FEW RATE APPROACH 30

2.4.4 THE RELAXED MOLECULAR CLOCKS: A MULTIPLE RATE APPROACH............................................................................... 31

2.4.5 THE FUTURE MOLECULAR CLOCKS: ACCURACY AND

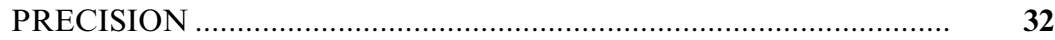

2.5 The Triple Clock of Life in the Solar System ...................................................... $\quad 32$

2.5.1 IS THERE A BEGINING? THE PROBLEM OF “TIME ZERO” AND THE LOGARITHMIC CLOCK …...................................................... 32

2.5.2 ASTRONOMY VS. GEOLOGICAL AND BIOLOGICAL CHRONOLOGIES: THE LINEAR CLOCKS

3 Solar System Formation and Early Evolution: the First 100 Million Years /

T. MONTMERLE, J.-C. AUGEREAU, M. CHAUSSIDON,

M. GOUNELLE, B. MARTY and A. MORBIDELLI.

3.1 The First Million Years: The "Stellar Era" ......................................................... 40

3.1.1 THE SUN'S BIRTHPLACE ......................................................... $\quad 40$

3.1.2 THE SUN AS A FORMING STAR …............................................. 46

3.1.3 A STELLAR VIEW OF THE "PRIMITIVE SOLAR NEBULA" ........ 5 
3.2 The First 10 Million Years: The "Disk Era"

3.2.1 THE EVOLUTION OF CIRCUMSTELLAR DISKS AROUND YOUNG STARS AND IMPLICATIONS FOR THE EARLY SOLAR SYSTEM

3.2.2 THE FIRST FEW MILLION YEARS AS RECORDED BY METEORITE DATA

3.2.3 INTERMEZZO

3.2.4 THE FIRST STAGES OF PLANETARY FORMATION IN THE SOLAR SYSTEM.

3.3 The First 100 Million Years: The "Telluric Era"

3.3.1 FORMATION OF THE TERRESTRIAL PLANETS AND PRIMORDIAL SCULPTING OF THE ASTEROID BELT

3.3.2 THE FORMATION OF THE MOON

3.3.3 TOWARDS 1 GYR: THE EARLY EVOLUTION OF THE EARTH

4 Building of a Habitable Planet / H. MARTIN, F. ALBARÈDE, P. CLAEYS,

M. GARGAUD, B. MARTY, A. MORBIDELLI and D.L. PINTI

97-151

4.1 Terrestrial Differentiation

98

4.1.1 BULK COMPOSITION OF THE EARTH ( 4.568 GA)

99

4.1.2 ENERGETIC OF PLANETARY DIFFERENTIATION PROCESSES.

100

4.1.3 THE CHRONOMETERS OF ACCRETION AND DIFFERENTIATION.

102

4.1.4 PETROLOGY OF PLANETARY DIFFERENTIATION

103

4.1.5 PLANETARY MAGMA OCEANS AND THE SURFACE OF THE PLANETS AT THE END OF ACCRETION $(\sim 4.56$ TO $\sim 4.45$ GA $) \ldots$.

4.1.6 THE EARLY CRUST: TOWARD PLATE TECTONICS AND CONTINENTS(4.5-4.4 GA).

106

4.2 Late Contributions

107

4.2.1 ATMOSPHERE

107

4.2.2 OCEAN

119

4.3 The First Continents

4.3.1 THE 3.8-3.9 GA ARCHAEAN CRUST.

4.3.2 THE 4.0 GA ARCHAEAN CRUST

4.3.3 THE PRE-4. GA HADEAN CRUST

4.4 Late Heavy Bombardment (LHB)

137

4.4.1 THE LATE HEAVY BOMBARDMENT (LHB)

137

4.4.2 ORIGIN OF THE LHB

5 Prebiotic Chemistry - Biochemistry - Emergence of Life (4.4-2 Ga) / R. PASCAL,

L. BOITEAU, P. FORTERRE, M. GARGAUD, A. LAZCANO, P. LÓPEZ-

GARCÍA, D. MOREIRA, M.-C. MAUREL, J. PERETÓ, D. PRIEUR and J. REISSE.

5.1 A Word of Caution About Chronology

5.2 A Scenario Starting From the First Chemical Building Blocks.

5.2.1 AVAILABILITY OF ORGANIC MATTER AND ENERGY

5.2.2 FAVOURABLE AREAS FOR PREBIOTIC CHEMICAL PROCESSES. 
5.2.3 CHEMICAL EVOLUTION THROUGH A STEPWISE PROCESS ...

5.2.4 CHEMICAL EVOLUTION THROUGH A DYNAMIC PROCESS ..

5.2.5 CATALYTIC ACTIVITY AND INFORMATION STORAGE ..........

5.3 Hypothesis about Early Metabolisms

5.3.1 PRELIMINARY DEFINITIONS

5.3.2 HOW THE FIRST ENTITIES PRESUMABLY GAINED THEIR ENERGY AND CARBON?....

5.4 Origin and Evolution of Compartments

5.4.1 AMPHIPHILIC VERSUS NON-AMPHIPHILIC COMPARTMENTS

5.4.2 SELF-ASSEMBLY AND EARLY EVOLUTION OF COMPARTMENTS

5.5 The Hypothesis of an RNA World

5.5.1 THE RNA WORLD SCRIPT

5.5.2 THE CASE OF ADENINE

5.5.3 PROVISIONAL CONCLUSIONS

5.6 The RNA/DNA Transition and the Origin of the Genetic Code

5.6.1 THE ORIGIN OF THE GENETIC CODE

5.6.2 DATING GENETIC TAKEOVERS: HOW OLD ARE CELLULAR DNA GENOMES?

5.7 The Last Common Ancestor.

5.7.1 PROTEIN SYNTHESIS IN THE CENANCESTOR

5.7.2 THE CENANCESTOR'S GENOME: DNA OR RNA?

5.7.3 ENERGY AND CARBON METABOLISM IN THE CENANCESTOR

5.7.4 THE MEMBRANE OF THE CENANCESTOR ….............................. 191

5.7.5 OTHER UNRESOLVED QUESTIONS .......................................... 192

5.8 The Origin of Viruses

193

5.8.1 VIRAL PROPERTIES

5.8.2 HYPOTHESES ON THE ORIGIN OF VIRUSES

195

6 Environmental Context / H. MARTIN, P. CLAEYS, M. GARGAUD, D.L. PINTI and F. SELSIS.

6.1 Evolution of Geological Mechanisms: The 2.5 Ga Transition

6.1.1 EPISODIC CRUSTAL GROWTH

6.1.2 GLOBAL EVOLUTION AND CHANGES ( 2.5 GA AGO)

6.1.3 CONCLUSION

6.2 Atmosphere and Ocean Physico-chemical Evolution

6.2.2 CHEMICAL EVOLUTION OF THE OCEANS................................. 22

6.3 Disturbing Events.

6.3.1 SPHERULE LAYERS: THE RECORD OF ARCHAEAN AND PROTEROZOIC IMPACT EVENTS.

6.3.2 THE PALEOPROTEROZOIC GLACIATIONS, THE FIRST SNOWBALL EARTH 
7 Ancient Fossil Record and Early Evolution (ca. 3.8 to 0.5 Ga) / P. LÓPEZ-GARCÍA, P. CLAEYS, E. DOUZERY, P. FORTERRE, D. MOREIRA, D. PRIEUR and M. VAN ZUILEN.

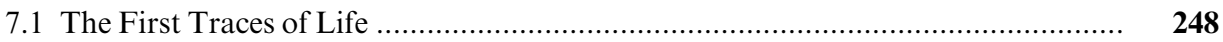

7.1.1 THE TRACERS ............................................................................ $\quad \mathbf{2 5 0}$

7.1.2 EXAMPLES FROM THE FIELD …............................................. $\quad 255$

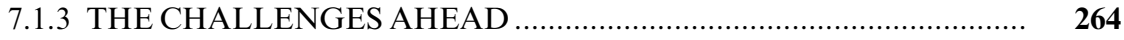

7.2 Microbial and Metabolic Diversification ......................................................... $\quad \mathbf{2 6 5}$

7.2.1 HOW DO CONTEMPORARY CELLS GAIN THEIR ENERGY?.... $26 \mathbf{2 6 5}$

7.2.2 WHAT WERE THE MOST PROBABLE MILESTONES? ................. $\quad \mathbf{2 6 7}$

7.3 The Origin of Eukaryotes ....................................................................... $\quad \mathbf{2 6 9}$

7.3.1 DIFFERENT HYPOTHESES FOR THE ORIGIN OF EUKARYOTES

7.3.2 THE LAST COMMON ANCESTOR OF CONTEMPORARY EUKARYOTES

7.3.3 WHEN DID EUKARYOTES APPEAR AND DIVERSIFY?............. 275

7.4 The Neoproterozoic-Cambrian Transition ( 1000 to $542 \mathrm{Ma})$.

8 A Synthetic Interdisciplinary "Chronological Frieze": an Attempt / D. DESPOIS and M. GARGAUD.

8.1 General Description .......................................................................... 291

8.2 How to Interpret the Data of the "Chronological Frieze"? ................................ 293

8.2.1 EON AND PHASE ................................................................ 293

8.2.2 AGE, ERROR BARS, TIME AND DURATION ............................ 293

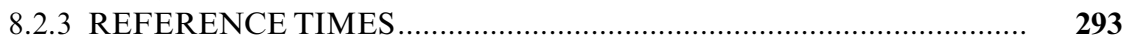

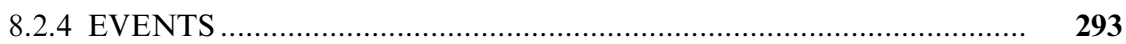

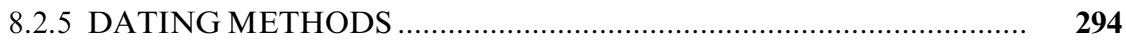

8.2.6 RELEVANT OBSERVATIONS ................................................... 294

8.2.7 RELIABILITY ........................................................................ 294

8.2.8 CONSEQUENCES FOR LIFE'S ORIGIN AND EVOLUTION ........ 294

8.2.9 REFERENCES ....................................................................... 294

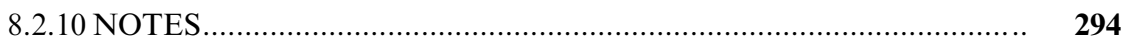

9 Life On Earth... And Elsewhere? / T. MONTMERLE, P. CLAEYS, M. GARGAUD, P. LÓPEZ-GARCÍA, H. MARTIN, R. PASCAL, J. REISSE and F. SELSIS ......... 299-312

9.1 The Chronology of Life in the Solar System: Highlights .................................... $\quad 300$

9.1.1 FROM THE BIRTH OF THE SUN TO THE BIRTH OF THE EARTH.

300

9.1.2 THE HISTORY OF THE EARLY EARTH AND GEOLOGICAL CONSTRAINTS ON THE ORIGIN OF LIFE ................................. $\quad \mathbf{3 0 2}$

9.1.3 FACTS OF LIFE .................................................................. $\quad 304$

9.2 Our World in Perspective: Is Life Universal? .................................................... $\quad 306$

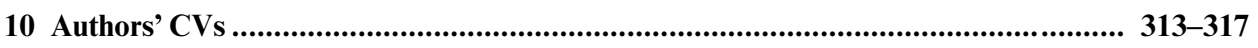

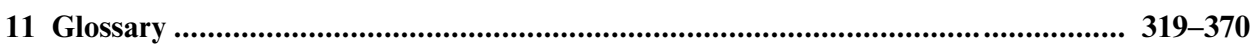

